\title{
The effect of hepcidin on components of metabolic syndrome in chronic kidney disease: a cross-sectional study
}

Sibel Gökçay Bek1

(iD) Berna Üstüner²

(iD) Necmi Eren ${ }^{1}$

(iD) Zeynep Sentürk ${ }^{2}$

Betül Kalender Gönüllü1

1. Assistant Professor, Nephrology Department, Kocaeli University Hospital, Internal Medicine, İzmit/Kocaeli, Turkey. 2. Resident in Internal Medicine, Kocaeli University Hospital, Internal Medicine, Izmit/Kocaeli, Turkey.

\section{SUMMARY}

BACKGROUND: Hepcidin is an important regulator of iron homeostasis.

OBJECTIVES: This cross-sectional study was conducted to evaluate the association between hepcidin and components of metabolic syndrome in patients with chronic kidney disease (CKD).

DESIGN AND SETTING: 103 CKD patients and 59 healthy volunteers were included in the study from the University Hospital.

METHODS: Serum hepcidin levels were measured by enyzme-linked immunosorbent assay (ELISA) test. As for the study parameters, age, sex, body mass index, renal diseases, serum biochemistry, complete blood count, iron and total iron-binding capacity, ferritin, high-sensitive C-reactive protein (hsCRP), C-reactive protein (CRP), and erythrocyte sedimentation rate (ESR) were evaluated.

RESULTS: The mean age of the patients was $58.63 \pm 11.8$ years. Hepcidin level was significantly associated with hypertension and higher uric acid levels $(P<0.05)$. There was a positive correlation between hepcidin and urea, uric acid, creatinine, ferritin, CRP, ESR, phosphorus, triglyceride, low-density lipoprotein ( $L D L)$, proteinuria and albuminuria in 24-hour urine collection. A negative correlation was found between hepcidin and estimated glomerular filtration rate (eGFR), hemoglobin, hematocrit, calcium, $25 \mathrm{OH}$ vitamin D, pH, and bicarbonate levels.

CONCLUSION: Hepcidin, a well-known hormone regulator of iron metabolism, may play an important role in the pathogenesis of metabolic syndrome in patients with CKD, and further studies might delineate in-depth its potential as a promising early marker in these patients. KEYWORDS: Hepcidins. Renal insufficiency, chronic. Metabolic syndrome.

\section{INTRODUCTION}

The metabolic syndrome (MetS) is a condition highly prevalent worldwide, involving nearly onefourth of the adult population and chronic kidney disease (CKD) patients in all stages. ${ }^{1}$ MetS is a combination of hyperglycemia, dyslipidemia, hypertension, and obesity, ${ }^{2}$ leading to increased risk for 
cardiovascular diseases, nonalcoholic fatty liver disease (NAFLD), and diabetes.

Excess body iron stores are frequently detected in subjects with insulin resistance and related metabolic alterations. ${ }^{3}$ The complex pathophysiological links between iron and metabolic disorders remain poorly clarified. ${ }^{3}$

Iron stores, expressed as serum ferritin concentration, are a component of insulin-resistance syndrome. Circulating ferritin has been shown to be associated with centrally distributed body fat and other measures of obesity. ${ }^{4,5}$ In the healthy population, ferritin levels were positively correlated with the serum glucose level. ${ }^{4}$ Ferritin levels were also correlated with diastolic arterial blood pressure after adjustment for BMI. ${ }^{4}$ Moirand et al. ${ }^{6}$ first reported the presence of histologically proven liver iron overload in overweight subjects with abnormal glucose metabolism and dyslipidemia. Similarly high hepcidin levels were linked to metabolic syndrome. ${ }^{7}$

Over the past ten years, hepcidin has emerged as the key iron-regulatory hormone. ${ }^{8}$ This defensin-like 25 amino acid peptide is mainly produced by the liver in response to increased plasma or tissue iron to homeostatically downregulate the absorption and recycling of the metal. ${ }^{9}$

Animal studies have shown that hepcidin is directly induced by insulin ${ }^{10}$ and down-regulated in high-fat/ high-energy diet-induced insulin resistance. ${ }^{11}$ Moreover, hepcidin levels have been found to be increased in obesity because of autonomous production in adipose tissue,$^{12}$ independently of insulin resistance, whereas a high-fat diet reduced hepcidin levels because of impaired iron absorption. ${ }^{13}$ In severe obesity, serum hepcidin concentrations were found to be elevated without true iron deficiency ${ }^{12}$.

Hepcidin levels that were inadequately low in relation to body iron status have recently been reported in subjects with type 2 diabetes $^{14}$ and suggest relative hepcidin deficiency as a potential cause of diabetes-related iron overload similar to that observed in genetic hemochromatosis. ${ }^{15,16}$ Hepcidin may represent signals from obese adipose tissue that dysregulate not only iron homeostasis but also components of metabolic syndrome.

\section{OBJECTIVES}

This study aimed to investigate the relationship between hepcidin and the main parameters of MetS in CKD.

\section{METHODS}

\section{Patient characteristics}

This is a cross-sectional and observational study that enrolled 103 CKD patients and 59 healthy volunteers. Informed consent of the participants and approval by the local ethics committee were obtained before the study (KAEK/KOU 2012/29). The exclusion criteria were: presence of an acute infection, history of malignancy, pregnancy, age under 18 years or over 80 years, parenteral iron replacement or blood transfusion within six months, history of bleeding within four weeks, history of bleeding disorders, treatment of erythropoietin stimulating agents within the past two months, history of liver disease or Hepatitis B or Hepatitis C infection, corticosteroid treatment, history of hemochromatosis or thalassemia, history of hyperparathyroidism, or renal replacement therapy within the last two months.

\section{Study design}

The patients' demographic characteristics, anthropometric measurements, body mass indexes (BMI), history of smoking and medical treatment, modality of renal replacement treatment, and etiology of renal failure were recorded. Blood samples were obtained after at least eight hours of fasting and before the peritoneal or hemodialysis session. Three milliliters of samples for hepcidin measurement were centrifugated at $3000 \mathrm{rpm}$ for ten minutes and frozen at $-20{ }^{\circ} \mathrm{C}$ until they were analyzed.

For all patients, the tests of complete blood count, plasma albumin, total cholesterol, low-density lipoprotein (LDL), high-density lipoprotein (HDL), triglycerides (TG), blood urea nitrogen (BUN), creatinine, C-reactive protein (CRP), high sensitive CRP, alkaline phosphatase (ALP), sodium (Na), potassium (K), calcium (Ca), phosphate (P), parathyroid hormone (PTH) levels, 25-OH vitamin $\mathrm{D}$, ferritin, iron, serum iron-binding capacity (SIBC), vitamin B12, folic acid, uric acid, thyroid hormones, lipid profile, Hepatitis B surface antigen

(HbsAg), antiHbs, antiHCV, venous blood gas analysis, creatinine clearance, microalbuminuria, and daily proteinuria were obtained.

Plasma hepcidin-25 levels were measured using enzyme immunoassay (EIA) method (Competition ELISA; DRG İnternational inc, USA). Results were expressed in $\mathrm{pg} / \mathrm{ml}$.

\section{Statistical methods}

Statistical analysis was performed using SPSS for Windows (Version 17.0, Chicago, USA). The 
distribution of the dataset was evaluated prior to the analyses. The association between hepcidin level and measured variables was evaluated using Spearman's rank correlation coefficient (rho). Normally distributed categorical variables were described using counts and percentages, with the mean value ( \pm standard deviation) used to describe continuous variables. Non-normally distributed variables were described by the median and range (minimum-maximum). Between-group differences (CKD versus control group) were evaluated using the Mann-Whitney U Test for non-parametric variables and Student's t-test for parametric variables. Comparisons of independent variables between groups were evaluated using the Kruskal-Wallis test for non-parametric data. A comparison of dependent variables between the two groups was performed using the Wilcoxon test. For all analyses, significance was set at $\mathrm{P}<0.05$.

\section{RESULTS}

The study population consisted of 103 CKD patients [ $\mathrm{n}=103,46$ females, mean \pm standard error of the mean (SEM) age $58.63 \pm 11.8]$ and 59 healthy volunteers $[n=59,29$ females, mean ( \pm SEM) age 49.0 $\pm 10.5]$. The demographic and biochemical characteristics of the study population are given in Table 1.

As for the comorbidities, 61 (59.2\%) patients had diabetes mellitus (DM), 90 (87.4\%) hypertension, 24 (23.3\%) coronary heart disease (CHD), 13 (12.6\%) congestive heart failure (CHF), 5 (4.9\%) cerebrovascular disease (CVD), 3 (2.9\%) pulmonary artery hypertension (PAH), 9 (8.7\%) hypothyroidism, and 4 (3.9\%) nephrolithiasis.

Out of 103 patients, $63(61.2 \%)$ were using Angiotensin II receptor blockers (ARB), 25 (24.3\%) angiotensin-converting-enzyme inhibitors (ACEinh), 26 (25.2\%) Ca channel blockers, 7 (6.8\%) essential amino-acids, 14 (13.6\%) alfa blockers, 29 (28.2\%) diuretics, 42 (40.8\%) beta-blockers, 34 (33\%) statins, 11 (10.7\%) phosphate binders, 8 (7.8\%) active vitamin D, $30(29.1 \%)$ insulin, 21 (20.4\%) oral antidiabetics, 31 (30.1\%) acetylsalicylic acid, and 25 (24.3\%) proton pomp inhibitors. The association between hepcidin and treatment with bicarbonate $(p=0.001)$, essential aminoacids $(\mathrm{p}=0.016)$, phospate binders $(\mathrm{p}=0.002)$, allopurinol $(\mathrm{p}=0.001)$, active vitamin $\mathrm{D}(\mathrm{p}=0.002)$, and oral antidiabetics $(p=0.013)$ were significant while there was no association between hepcidin and treatment with statins, ACEinh, ARB, Ca channel blockers, alfa blocker, diuretics, beta blockers, and vitamin D.

No correlation was found between hepcidin and glucose levels. But a negative correlation between glucose and iron $(\mathrm{P}=0.004, \mathrm{r}=-0.227)$ was observed. There was no significant difference between hepcidin levels based on the presence or absence of diabetes mellitus (Mann-Whitney U, $\mathrm{P}=0.072, \mathrm{r}=-0.178, \mathrm{P}=0.072$ ).

TABLE 1. DEMOGRAPHIC AND BIOCHEMICAL CHARACTERISTICS OF THE STUDY GROUP

\begin{tabular}{|c|c|c|c|}
\hline & $\begin{array}{l}\text { Patients }(n= \\
103)\end{array}$ & $\begin{array}{l}\text { Control (n } \\
=59)\end{array}$ & $\mathrm{P}$ \\
\hline Age, years & $58.6 \pm 11.8$ & $49.0 \pm 10.5$ & 0.0001 \\
\hline Male, n (\%) & $57(55.3)$ & $30(50.8)$ & \\
\hline Female, n (\%) & $46(44.7)$ & $29(49.2)$ & \\
\hline Height, cm & $163.3 \pm 8.7$ & $163.4 \pm 9.5$ & 0.947 \\
\hline Weight, kg & $77.3 \pm 13.5$ & $72.9 \pm 12.1$ & 0.083 \\
\hline $\mathrm{BMI}, \mathrm{kg} / \mathrm{m}^{2}$ & $28.3 \pm 5.5$ & $27.0 \pm 4.4$ & 0.302 \\
\hline Glucose, mg/dL & $131.7 \pm 65.8$ & $88.5 \pm 13.3$ & 0.0001 \\
\hline Creatinine, mg/dL & $2.1 \pm 2.1$ & $0.7 \pm 0.1$ & 0.0001 \\
\hline Urea, mg/dL & $74.8 \pm 56.5$ & $29.9 \pm 6.6$ & 0.0001 \\
\hline $\mathrm{TSH}, \mathrm{ulU} / \mathrm{mL}$ & $1.9 \pm 2.9$ & $2.3 \pm 4.5$ & 0.246 \\
\hline Vitamin B12, pg/mL & $328 \pm 252$ & $234 \pm 134$ & 0.005 \\
\hline Folic acid, ng/mL & $9.2 \pm 13.4$ & $8 \pm 2.8$ & 0.405 \\
\hline $\mathrm{HDL}, \mathrm{mg} / \mathrm{dL}$ & $42.7 \pm 11.4$ & $46.8 \pm 11.6$ & 0.721 \\
\hline $\mathrm{LDL}, \mathrm{mg} / \mathrm{dL}$ & $118.1 \pm 35.1$ & $127.9 \pm 32.4$ & 0.307 \\
\hline $\begin{array}{l}\text { Creatinine clearance, } \mathrm{ml} / \\
\text { min }\end{array}$ & $52.1 \pm 38.4$ & & \\
\hline $\begin{array}{l}\text { Albuminuria in 24-h urine, } \\
\mathrm{mg} / \text { day }\end{array}$ & $900.6 \pm 1787.0$ & & \\
\hline $\begin{array}{l}\text { Proteinuria in 24-h urine, } \\
\text { mg/day }\end{array}$ & $1454.1 \pm 2632.4$ & & \\
\hline PTH, pg/mL & $101.0 \pm 114.7$ & $47.5 \pm 17.7$ & 0.0001 \\
\hline Vitamin D $25 \mathrm{OH}, \mathrm{ng} / \mathrm{mL}$ & $18.7 \pm 11.8$ & $17.0 \pm 6.9$ & 0.671 \\
\hline Albumin, mg/dL & $4.0 \pm 0.4$ & $4.4 \pm 0.2$ & 0.001 \\
\hline Calcium, mg/dL & $9.1 \pm 0.6$ & $8.8 \pm 0.3$ & 0.0001 \\
\hline Phosphate, mg/dL & $3.7 \pm 1.2$ & $3.1 \pm 0.5$ & 0.001 \\
\hline Magnesium, mg/dL & $2.2 \pm 0.2$ & $2.3 \pm 0.3$ & 0.262 \\
\hline ALP, U/L & $86.3 \pm 28.9$ & $84.2 \pm 28.9$ & 0.469 \\
\hline Uric acid, mg/dL & $6.3 \pm 1.9$ & $4.6 \pm 1.1$ & 0.0001 \\
\hline Hepcidin, ng/ml & $30.3 \pm 24.7$ & $17.8 \pm 8.4$ & 0.016 \\
\hline eGFR, $\mathrm{ml} / \mathrm{min}$ & $44.2 \pm 30.6$ & $100.8 \pm 15.8$ & 0.0001 \\
\hline Haemoglobin, g/dL & $12.6 \pm 1.8$ & $14.2 \pm 1.3$ & 0.01 \\
\hline Haematocrit, \% & $38.3 \pm 5.6$ & $43.2 \pm 3.7$ & 0.002 \\
\hline $\mathrm{MCV}, \mathrm{fL}$ & $90.3 \pm 5.4$ & $91.4 \pm 4.6$ & 0.368 \\
\hline MPV, fL & $7.9 \pm 1$ & $7.7 \pm 1.1$ & 0.545 \\
\hline Serum ferritin, ng/mL & $90.6 \pm 149.7$ & $47.4 \pm 44.1$ & 0.041 \\
\hline Serum iron, $\mu g / d L$ & $61.7 \pm 25.7$ & $82.5 \pm 30.8$ & 0.0001 \\
\hline $\begin{array}{l}\text { Serum transferrin satura- } \\
\text { tion, } \%\end{array}$ & $21.7 \% \pm 9.0$ & $27.6 \pm 11.0$ & 0.001 \\
\hline
\end{tabular}

$\mathrm{BMI}=$ body mass index; $\mathrm{TSH}=$ thyroid-stimulating hormone; $\mathrm{HDL}=$ high-density lipoprotein; $\mathrm{PTH}=$ parathyroid hormone; $\mathrm{ALP}=$ alkaline phosphatase, eGFR = estimated glomerular filtration rate; $\mathrm{MCV}=$ mean corpuscle volume; $\mathrm{MPV}=$ mean platelet volume.

$P$-value determined by the Mann-Whitney $U$ test; 
However, the mean hepcidin level of non-diabetic patients $(22.8 \pm 26.4)$ was higher than those with DM (19.2 \pm 23$)$.

The mean hepcidin level $(30.3 \pm 24.7 \mathrm{ng} / \mathrm{ml})$ of patients was higher than the control group $(17.8 \pm 8.4$ $\mathrm{ng} / \mathrm{ml}),(\mathrm{P}<0.05)$. The hepcidin level was significantly associated with hypertension $(\mathrm{P}<0.05)$. There was a positive correlation between hepcidin and urea, uric acid, creatinine, ferritin, CRP, ESR, phosphorus, proteinuria, and albuminuria in 24-hour urine collection. A negative correlation was found between hepcidin and creatinine clearance, eGFR, hemoglobin, hematocrit, calcium, $25 \mathrm{OH}$ vitamin $\mathrm{D}, \mathrm{Ph}$, and bicarbonate levels (Table 2 and Figure 1).

\section{DISCUSSION}

Hepcidin is a well-known regulator of body iron metabolism. In recent years more evidence supports its effect on glucose and lipid metabolism. In a study by Aigner et al. ${ }^{17}$, serum iron concentrations decreased following $75 \mathrm{~g}$ oral glucose, and hepcidin concentrations increased within the first 120 minutes of oral glucose. These results indicate that glucose negatively

TABLE 2. CORRELATION BETWEEN HEPCIDIN LEVEL AND LABORATORY-BASED VARIABLES IN THE CHRONIC KIDNEY DISEASE (CKD) GROUP

\begin{tabular}{|c|c|c|}
\hline Correlation of hepcidin & $\mathrm{R}$ & $P$ \\
\hline Glucose & -0.051 & 0.611 \\
\hline BUN & 0.615 & 0.0001 \\
\hline Urea & 0.617 & 0.0001 \\
\hline eGFR & -0.522 & 0.0001 \\
\hline $\mathrm{Hb}$ & -0.431 & 0.0001 \\
\hline Sedimentation & 0.374 & 0.0001 \\
\hline sCRP & 0.397 & 0.0001 \\
\hline CRP & 0.343 & 0.0001 \\
\hline Ferritin & 0.737 & 0.0001 \\
\hline Iron & -0.177 & 0.024 \\
\hline Transferrin Saturation & 0.155 & 0.119 \\
\hline LDL & 0.477 & 0.002 \\
\hline Uric acid & 0.152 & 0.002 \\
\hline Creatinine clearance in $24-h$ urine & -0.549 & 0.0001 \\
\hline Albuminuria in 24-h urine & 0.305 & 0.002 \\
\hline Proteinuria in 24 -h urine & 0.300 & 0.002 \\
\hline Serum albumin & -0.396 & 0.0001 \\
\hline Calcium & -0.428 & 0.0001 \\
\hline Phosphate & 0.454 & 0.0001 \\
\hline TG & 0.367 & 0.002 \\
\hline
\end{tabular}

eGFR = estimated glomerular filtration rate; $\mathrm{BUN}=$ blood urea nitrogen; $\mathrm{Hb}=$ haemoglobin; $\mathrm{SCRP}=$ sensitive $\mathrm{C}$-reactive protein; $\mathrm{CRP}=\mathrm{C}$-reactive protein; $\mathrm{LDL}=$ low-density lipoprotein; $\mathrm{TG}=$ triglyceride. regulates iron metabolism and positively stimulates hepcidin release from pancreatic beta cells. However, in our study, we did not find such a correlation between hepcidin and glucose levels. However, a significant negative correlation between glucose and iron was observed, which is consistent with the previous studies. Diabetes mellitus by itself was not related to low hepcidin levels according to our study. Similarly, there was no correlation between BMI and hepcidin levels. There are many conditions like chronic inflammation associated with high hepcidin levels besides high glucose levels and dyslipidemia in CKD.

Insulin resistance, but not insulin deficiency or hyperglycemia, is associated with inadequate hepcidin levels. Reduced hepcidin concentrations may cause increased body iron stores in insulin-resistant states. ${ }^{18,19}$ Patients with Type 2 diabetes had significantly lower serum hepcidin and hepcidin/ferritin ratio than weight-matched controls. There was a significant negative correlation between the serum hepcidin/ferritin ratio and homeostasis model assessment of insulin resistance. ${ }^{14,19}$ Inadequate hepcidin levels for the iron load in patients with Type 2 diabetes were related to increased body iron and insulin resistance. ${ }^{18}$ Hepcidin levels that are inadequately low in relation to body iron stores are an independent predictor for incident Type 2 diabetes and may contribute to diabetes-related tissue iron overload. In conclusion, inadequately low hepcidin is a probable independent predictor of incident Type 2 diabetes. ${ }^{20,21}$

An increased iron load is a risk factor for hypertension, cardiovascular diseases, and MetS. ${ }^{21-23}$ It also destroys pancreatic beta cells and leads to insulin resistance and the development of Type 2 diabetes. ${ }^{24} \mathrm{In}$ a study conducted by Wang et al. ${ }^{10}$, in streptozocin-induced diabetic rats, hepatic hepcidin levels decreased prominently. As a result, intestinal iron absorption, serum iron, and hepatic iron increased. Similarly, in diabetic patients after pancreatic cell damage, hepcidin levels decrease and iron accumulation is commonly observed. In our patients who were taking oral antidiabetic treatment, we found significantly lower levels of hepcidin compared to those not taking the drug. A low level of hepcidin in diabetic patients with decreased beta-cells is an expected finding.

Hyperuricemia is associated with so-called "cardio-metabolic diseases” including cardiovascular disease and MetS. ${ }^{25}$ In hyperuricemic patients; hypertension, hyperinsulinemia, hypertriglyceridemia, and diabetes are reported with a higher prevalence of MetS. 
FIGURE 1. CORRELATIONS OF HEPCIDIN WITH LOW-DENSITY LIPOPROTEIN (LDL), TRIGLYCERIDES (TG), C-REACTIVE PROTEIN (CRP), SERUM C-REACTIVE PROTEIN (SCRP), 24-HOUR URINARY ALBUMIN
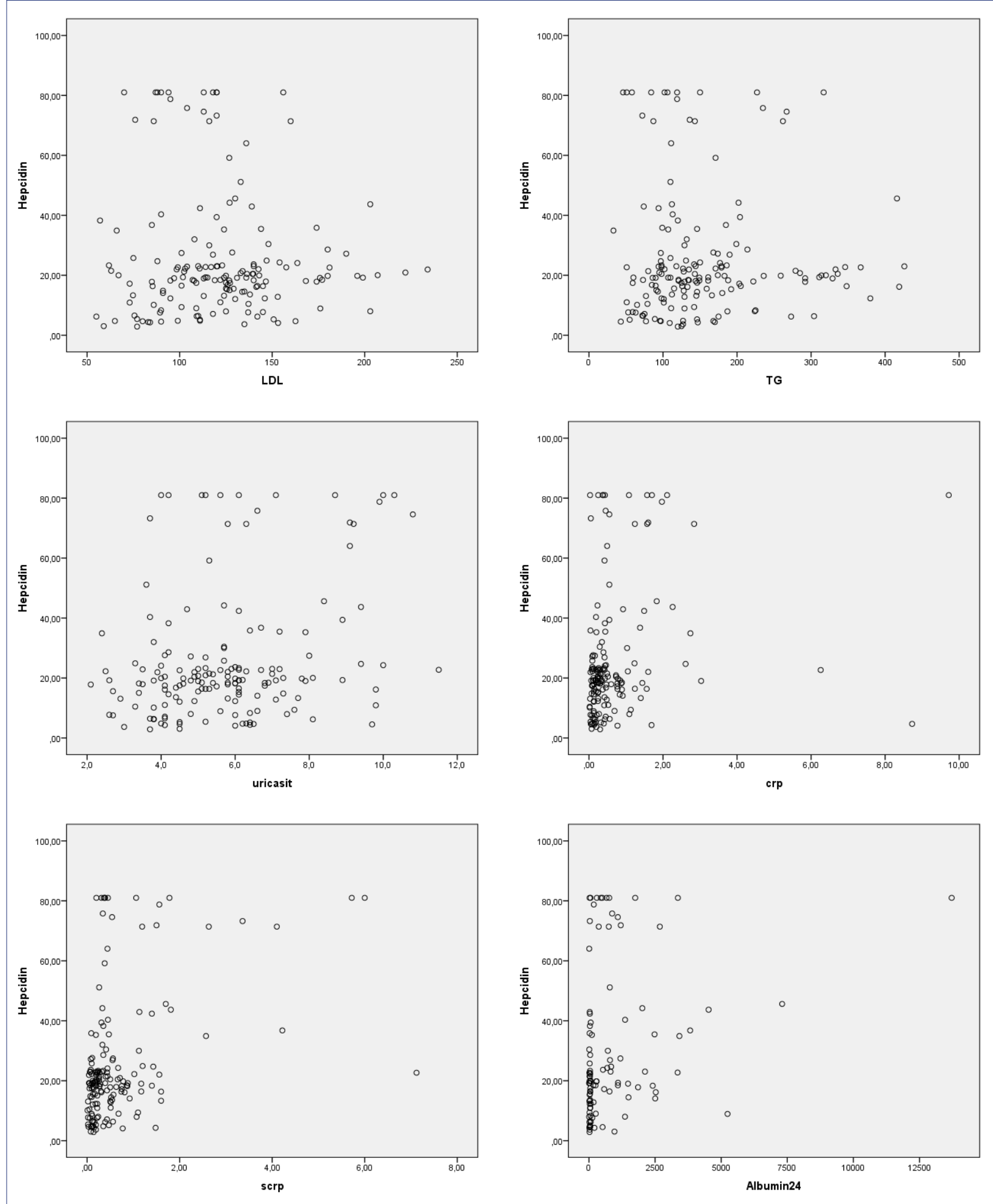

Hyperuricemia is an indicator for early diagnosis of MetS and its clinical manifestations. ${ }^{26-28}$ In a meta-analysis of prospective cohort studies, it is shown that hyperuricemia is a risk factor for developing Type 2 diabetes in middle-aged and older people, independently of other established metabolic risk factors. ${ }^{29}$
In our study, there was a statistically significant positive correlation between hepcidin and serum uric acid levels in CKD patients and healthy volunteers. We also found a statistically significant positive correlation between uric acid and SCRP, CRP, and sedimentation levels in the patient group. Hyperuricemia 
is a significant risk factor for atherosclerosis, MetS, hypertension, and worsening of insulin resistance. Lobo et al. ${ }^{30}$ investigated the relationship between uric acid and inflammation in hemodialysis patients and reported a positive correlation between the uric acid level and inflammatory markers. In hemodialysis patients, uric acid levels were found to be higher than in the control group. There are no similar studies in the literature comparing hepcidin with uric acid levels. However, it can be considered that uric acid levels might increase indirectly with inflammation. In fact, the relationship between uric acid and hepcidin is more like a vicious cycle affecting both sides, ultimately leading to adverse effects on cardiovascular health and increasing the risk of MetS in CKD.

In our study, there was a positive correlation between triglyceride (TG) and hepcidin and negative correlation between HDL and hepcidin. As an important contributor to MetS, lipid levels were found to be significantly associated with hepcidin. In the literature, there is one study evaluating this relationship in kidney transplant patients reporting a positive correlation between hepcidin and hyperlipidemia. ${ }^{31} \mathrm{In}$ a study evaluating the effect of hepcidin on systolic blood pressure in healthy individuals, Suárez-Ortegón et al..$^{32}$ reported a significant association between hepcidin and TG in healthy women. In our study, we found significantly higher levels of inflammatory markers in CKD patients, thus supporting the presence of ongoing chronic inflammation, commonly seen in these patients. Chronic inflammation leads to increased hepcidin and this, in turn, leads to disorders of iron homeostasis, inducing iron overload with elevated serum ferritin. The presence of hyperlipidemia with chronic inflammation leads to further renal injury and cardiovascular diseases. In a study by Li et al. ${ }^{33}$ hepcidin levels were analyzed in hemodialysis patients with diabetes mellitus. Increased serum hepcidin levels in hemodialysis patients with diabetes mellitus, when compared to non-diabetic patients and the general population, were found to be an important contributor to atherosclerosis and cardiovascular risk factors. In a hyperlipidemic mouse model, hepcidin deficiency was found to be associated with low macrophage iron, a decreased aortic macrophage inflammatory phenotype, and protection against atherosclerosis. This shows that low hepcidin activity and related reduced macrophage iron might be a potential therapeutic strategy in the prevention of atherosclerosis ${ }^{34}$.

Similar to our findings, the relationship between hepcidin and metabolic syndrome in CKD was shown in previous studies ${ }^{7,14}$. Hypertension was also found to be related to high hepcidin levels in our study. The effect of hepcidin levels on systolic blood pressure, especially in men, was also demonstrated in healthy indivuals ${ }^{32}$. Proteinuria was positively correlated with hepcidin independently from blood pressure readings, blood glucose levels, and eGFR in our patients. It is known that serum hepcidin-25 levels are not dependent on eGFR but hepcidin isoforms can accumulate with renal impairment ${ }^{35}$. Similarly, in a study evaluating the hepcidin effect on the progression of CKD, hepcidin was related to mortality, along with greater proteinuria and elevated $\mathrm{CRP}^{36}$. In this study, hepcidin was considered to be a predictor for the progression of CKD, besides baseline eGFR, proteinuria, low albumin, and Hb levels and the presence of CKD. These facts also strengthen the possible role of hepcidin in predicting CKD progression.

It is well documented that hepcidin is a marker in the MetS associated with hyperferritinemia ${ }^{37}$. Our results on CKD patients suggest that hepcidin is involved in the MetS pathophysiology and, thus, it might be used as an early marker for MetS in these patients.

In conclusion, hyperhepcidinemia might be another important prognostic feature of MetS. The exact role of hepcidin in the progression of insulin resistance, atherosclerosis, and CKD needs to be further clarified in future research.

\section{Author's Contribution}

Conceptualization: Sibel Bek; Data curation: Berna Ustuner, Necmi Eren, Zeynep Senturk, Sibel Bek; Formal analysis: Berna Ustuner, Sibel Bek; Funding acquisition: Sibel Bek; Investigation: Berna Ustuner, Necmi Eren, Sibel Bek; Methods: Berna Ustuner, Necmi Eren, Zeynep Senturk, Sibel Bek; Project administration: Sibel Bek; Resources: Berna Ustuner, Sibel Bek; Software: Berna Ustuner, Sibel Bek; Supervision: Necmi Eren, Betul Kalender, Sibel Bek; Validation: Sibel Bek; Visualization: Sibel Bek; Writing of the original draft: Berna Ustuner, Sibel Bek; Review and editting: Berna Ustuner, Necmi Eren, Betul Kalender, Sibel Bek 


\section{RESUMO}

FUNDAMENTO: A hepcidina é um importante regulador da homeostase do ferro.

OBJETIVOS: Este estudo transversal foi realizado para avaliar a associação entre hepcidina e componentes da síndrome metabólica em pacientes com doença renal crônica (DRC).

PROJETO E LOCAL: Cento e três pacientes com DRC e 59 voluntários saudáveis foram incluídos no estudo no Hospital Universitário.

MÉTODOS: Os níveis séricos de hepcidina foram medidos pelo teste imunoenzimático (Elisa). Quanto aos parâmetros do estudo, idade, sexo, índice de massa corporal, doenças renais, bioquímica sérica, hemograma completo, capacidade de ligação total de ferro e ferro, ferritina, proteína C reativa altamente sensivel (hs CRP), proteína C reativa (PCR) e taxa de sedimentação de eritrócitos (VHS) foram avaliados.

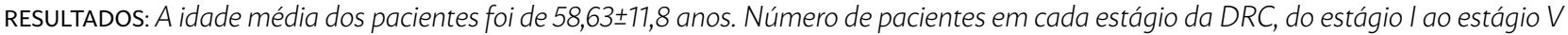
(não em terapia renal substitutiva). O nível de hepcidina foi significativamente associado à hipertensão e níveis mais altos de ácido úrico $(P<0,05)$. Houve correlação positiva entre hepcidina e ureia, ácido úrico, creatinina, ferritina, $P C R, V H S$, fósforo, triglicerídeo, lipoproteína de baixa densidade ( $L D L)$, proteinúria e albuminúria na coleta de urina de 24 horas. Foi encontrada correlação negativa entre hepcidina e taxa de filtração glomerular estimada (TFGe), hemoglobina, hematócrito, cálcio, $25 \mathrm{OH}$ de vitamina D, pH e níveis de bicarbonato.

CONCLUSÃo: A hepcidina é um hormônio bem conhecido que regula o metabolismo do ferro, mas também pode ser um importante contribuinte para os componentes da síndrome metabólica em pacientes com DRC.

PALAVRAS-CHAVE: Hepcidinas. Insuficiência renal crônica. Síndrome metabólica.

\section{REFERENCES}

1. Ford ES, Giles WH, Dietz WH. Prevalence of the metabolic syndrome among US adults: findings from the third National Health and Nutrition Examination Survey. JAMA. 2002;287(3):356-9.

2. Alberti KG, Eckel RH, Grundy SM, Zimmet PZ, Cleeman II, Donato KA et al; International Diabetes Federation Task Force on Epidemiology and Prevention; National Heart, Lung, and Blood Institute; American Heart Association; World Heart Federation; International Atherosclerosis Society; International Association for the Study of Obesity. Harmonizing the metabolic syndrome: a joint interim statement of the International Diabetes Federation Task Force on Epidemiology and Prevention; National Heart, Lung, and Blood Institute; American Heart Association; World Heart Federation; International Atherosclerosis Society; and International Association for the Study of Obesity. Circulation. 2009;120(16):1640-5.

3. Dongiovanni P, Fracanzani AL, Fargion S, Valenti L. Iron in fatty liver and in the metabolic syndrome: a promising therapeutic target. J Hepatol. 2011;55(4):920-32.

4. Fernández-Real JM, López-Bermejo A, Ricart W. Cross-talk between iron metabolism and diabetes. Diabetes. 2002;51(8):2348-54.

5. Gillum RF. Association of serum ferritin and indices of body fat distribution and obesity in Mexican American men-the Third National Health and Nutrition Examination Survey. Int J Obes Relat Metab Disord. 2001;25(5):639-45.

6. Moirand R, Mortaji AM, Loréal O, Paillard F, Brissot P, Deugnier Y, et al. A new syndrome of liver iron overload with normal transferrin saturation. Lancet. 1997;349(9045):95-7.

7. Martinelli N, Traglia M, Campostrini N, Biino G, Corbella M, Sala C, et al. Increased serum hepcidin levels in subjects with the metabolic syndrome: a population study. PloS One. 2012;7(10):e48250.

8. Ganz T. Hepcidin and iron regulation, 10 years later. Blood. 2011;117(17):4425-33.

9. Hentze MW, Muckenthaler MU, Galy B, Camaschella C. Two to tango: regulation of Mammalian iron metabolism. Cell. 2010;142(1):24-38.

10. Wang $H$, Li H, Jiang $X$, Shi W, Shen Z, Li M. Hepcidin is directly regulated by insulin and plays an important role in iron overload in streptozotocin-induced diabetic rats. Diabetes. 2014;63(5):1506-18.

11. Le Guenno G, Chanséaume E, Ruivard M, Morio B, Mazur A. Study of iron metabolism disturbances in an animal model of insulin resistance. Diabetes Res Clin Pract. 2007;77(3):363-70.

12. Bekri S, Gual P, Anty R, Luciani N, Dahman M, Ramesh B, et al. Increased adipose tissue expression of hepcidin in severe obesity is independent from diabetes and NASH. Gastroenterology. 2006;131(3):788-96.

13. Sonnweber T, Ress C, Nairz M, Theurl I, Schroll A, Murphy AT, et al. High-fat diet causes iron deficiency via hepcidin-independent reduction of duodenal iron absorption. J Nutr Biochem. 2012;23(12):1600-8.

14. Sam AH, Busbridge $M$, Amin A, Webber L, White D, Franks S, et al. Hepcidin levels in diabetes mellitus and polycystic ovary syndrome. Diabet Med. 2013;30(12):1495-9.
15. Weiss G. Genetic mechanisms and modifying factors in hereditary hemochromatosis. Nat Rev Gastroenterol Hepatol. 2010;7(1):50-8.

16. Pietrangelo A. Hemochromatosis: an endocrine liver disease. Hepatology. 2007:46(4):1291-301.

17. Aigner E, Felder TK, Oberkofler H, Hahne P, Auer S, Soyal S, et al. Glucose acts as a regulator of serum iron by increasing serum hepcidin concentrations. J Nutr Biochem. 2013;24(1):112-7.

18. Simcox JA, McClain DA. Iron and diabetes risk. Cell Metab. 2013;17(3):329-41.

19. Luque-Ramírez M, Alvarez-Blasco F, Botella-Carretero JI, Sanchón R, San Millán JL, Escobar-Morreale HF. Increased body iron stores of obese women with polycystic ovary syndrome are a consequence of insulin resistance and hyperinsulinism and are not a result of reduced menstrual losses. Diabetes Care. 2007;30(9):2309-13.

20. Pechlaner R, Weiss G, Bansal S, Mayr M, Santer P, Pallhuber B, et al. Inadequate hepcidin serum concentrations predict incident type 2 diabetes mellitus. Diabetes Metab Res Rev. 2006;32(2):187-92.

21. Sheu WH, Chen YT, Lee WJ, Wang CW, Lin LY. A relationship between serum ferritin and the insulin resistance syndrome is present in non-diabetic women but not in non-diabetic men. Clin Endocrinol (Oxf). 2003;58(3):380-5.

22. Piperno A, Trombini P, Gelosa M, Mauri V, Pecci V, Vergani A, et al. Increased serum ferritin is common in men with essential hypertension. J Hypertens. 2002;20(8):1513-8.

23. Ma J, Stampfer MJ. Body iron stores and coronary heart disease. Clin Chem. 2002;48(4):601-3.

24. Fernández-Real JM, Peñarroja G, Castro A, García-Bragado F, Hernández-Aguado I, Ricart W, et al. Blood letting in high-ferritin type 2 diabetes: effects on insulin sensitivity and beta-cell function. Diabetes. 2002;51(4):1000-4.

25. Zhang ML, Gao YX, Wang X, Chang H, Huang GW. Serum uric acid and appropriate cutoff value for prediction of metabolic syndrome among Chinese adults. J Clin Biochem Nutr. 2013;52(1):38-42.

26. Choi HK, Ford ES. Prevalence of the metabolic syndrome in individuals with hyperuricemia. Am J Med. 2007;120(5):442-7.

27. Kodama S, Saito K, Yachi Y, Asumi M, Sugawara A, Totsuka K, et al. Association between serum uric acid and development of type 2 diabetes. Diabetes Care. 2009;32(9):1737-42.

28. Lin SD, Tsai DH, Hsu SR. Association between serum uric acid level and components of the metabolic syndrome. J Chin Med Assoc. 2006;69(11):512-6.

29. Lv Q, Meng XF, He FF, Chen S, Su H, Xiong J, et al. High serum uric acid and increased risk of type 2 diabetes: a systemic review and meta-analysis of prospective cohort studies. PLoS One. 2013;8(2):e56864. 
30. Lobo JC, Stockler-Pinto MB, Nóbrega AC, Carraro-Eduardo JC, Mafra D. Is there association between uric acid and inflammation in hemodialysis patients? Ren Fail. 2013;35(3):361-6.

31. Xue D, He X, Zhou C. Serum hepcidin level correlates with hyperlipidemia status in patients following allograft renal transplantation. Transplant Proc. 2014;46(1):156-9.

32. Suárez-Ortegón MF, Arbeláez A, Mosquera M, Moreno-Navarrete JM, Aguilar-Plata C, Fernández-Real JM. Circulating hepcidin is independently associated with systolic blood pressure in apparently healthy individuals. Arch Med Res. 2015;46(6):507-13.

33. Li H, Feng SJ, Su LL, Wang W, Zhang XD, Wang SX. Serum hepcidin predicts uremic accelerated atherosclerosis in chronic hemodialysis patients with diabetic nephropathy. Chin Med J (Engl). 2015;128(10):1351-7.
34. Malhotra R, Wunderer F, Barnes HJ, Bagchi A, Buswell MD, O'Rourke CD, et al. Hepcidin deficiency protects against atherosclerosis. Arterioscler Thromb Vasc Biol. 2019;39(2):178-87.

35. Peters HP, Laarakkers CM, Swinkels DW, Wetzels JF. Serum hepcidin-25 levels in patients with chronic kidney disease are independent of glomerular filtration rate. Nephrol Dial Transplant. 2010;25(3):848-53.

36. Wagner M, Ashby DR, Kurtz C, Alam A, Busbridge M, Raff U, et al. Hepcidin-25 in diabetic chronic kidney disease is predictive for mortality and progression to end stage renal disease. PLoS One. 2015;10(4):e0123072.

37. Rauber MR, Pilger DA, Cecconello DK, Falcetta FS, Marcondes NA, Faulhaber GAM. Hepcidin is a useful biomarker to evaluate hyperferritinemia associated with metabolic syndrome. An Acad Bras Cienc. 2019;91(2):e20180286. 